\title{
CONSISTENCY CONCEPT IN VIRTUAL STRUCTURES - IN SEARCH FOR HARMONIZATION AS A CONDITION OF EFFECTIVE EXPLOITATION OF SIBERIAN CRITICAL SUCCESS FACTORS*
}

\author{
Michał Flieger** (i) http://orcid.org/0000-0002-8430-8883
}

\begin{abstract}
Background. New circumstances in which organizations operate give a new meaning to harmonization imperative which is still present in management theory as one of the most important issues. Today's harmonization is a base for consistency concept, the concept which requires searching for consistency platforms in organizations. One of harmonization aspects is matching cooperation mechanisms to corporate culture specific in various world regions. Because of borders opening and considerate potential of new regions more and more interest is placed in Siberian organizations which often have much to offer for their international partners. When Siberian organizations are defined to have Critical Success Factors they may be invited to take part in modern virtual structures and then they are responsible for operations taking place in one of the process nests. In such a case the Integrator of virtual organization as well as inside deliverers and inside clients need to focus on consistency mechanism during cooperation process. Knowing corporate culture of Siberian partners is necessary to be able to harmonize cooperation for better effectiveness of the venture.
\end{abstract}

Research aims. Considering above the main research aim is to provide typical characteristics of Siberian organizations' corporate culture. In the research such aspects as corporate culture artefacts are identified: language, behavior and material. Moreover, typical norms and values are pointed out and finally cultural traits which form the basis for the previously mentioned corporate culture aspects. The support research aim of the paper is to identify the directions which are expected by Siberian workers as for their corporate culture to be changed. This way the research also provides practical knowledge which may be of use for

* The publication is the result of scientific internship financed on the contest basis from the funds of Law and Administration Department of Adam Mickiewicz University in Poznań.

** Law and Administration Department, Adam Mickiewicz University, św. Marcina 90, Poznań 61-817, Poland. E-mail: m.flieger@wp.pl 
managers wanting to work out harmonization mechanism when cooperating with Siberian partners.

Methodology. To achieve above research aims the research was conducted in 2018 , within the period of three weeks in 40 Siberian organizations of different sizes and branches. All of them were business organizations. In the research such research methods were used as: questionnaires (156 questionnaires filled), interviews (30 interviews made) and direct observation (16 observations). Moreover, for identifying research background and for results discussion international literature studies have been made.

Key findings. The research results have shown that Siberian corporate culture is a specific mixture of Asian and European influences. It can be clearly seen in official and strict regulatory aspects of these organizations functioning on the one hand and in the importance of personal relations and informal aspects on the other hand. This specific dualism may be noticed in all of the culture levels which were researched. Moreover, Siberian corporate culture is specific because there are still strong communistic regime influences which mix with aggressive capitalism of the new era. That is why we can see community mechanism and friendly relations along with individualism and short time orientation for profits and career. As for findings considering expected directions of change, Siberian workers prefer friendly relations and the feel of community over strict orders and financial aspects of their work. These findings should be a starting point for scholars and managers to work out harmonization mechanisms between Siberian organizations and their native companies. As theoretical research have shown, there have not been any previous studies in management theory on Siberian corporate culture so far, so the research results presented in this paper are pioneer.

Keywords: corporate culture, Siberian organizations, consistency concept, harmonization.

JEL Codes: M16

\section{INTRODUCTION}

In today's reality of organizations' operations there tend to appear new circumstances in which they need to accommodate to sustain their competitiveness. Main changes which constitute organizational challenges are connected with opening borders as well as with changing clients' characteristics. Opening borders makes it possible for organizations to create new configurations in which the operations are conducted (Dziemianowicz, 1998, p. 45). When new areas of the world become open for cooperation, because for example political environment changes and invites foreign investments, organizations from other parts of the world may use the new resources in their favor. This way, new possibilities to create competitive advantages are created from time to 
time and it is necessary to be able to use these new opportunities to become more effective and efficient (Kuciński, 2001, p. 37).

Another circumstance that leads organizations to look for new cooperation possibilities is changing nature of clients who become more and more requiring. As the competition is fierce, the clients require more quality and flexibility, which makes organizations apply new organizational solutions (Drucker, 1992, pp. 24-30). To elevate clients' satisfaction to maximum level some unique ways of production and cooperation may be necessary and opening borders described above gives new opportunities to do so.

One of the ways to use resources from various parts of the world is organizing the structure in a virtual way (Chomiak-Orsa \& Flieger, 2011a, p. 198). Virtual structures mean dividing the production process into operations, deciding what critical success factors (CSFs) are needed to make the operation in the best way and finally inviting organizations having CSFs to cooperate with one another. Opening borders and searching for new CSFs leads organizations to explore new, often forgotten areas of the world in search for perfect cooperation structure.

However, when constructing such a structure there is a need to work on consistency problem which consistency concept brings up. When organizations from different parts of the world are cooperating it is necessary to harmonize their cooperation mechanisms so that the production process is smooth and efficient (Brol, 1997, p. 45). To sustain consistency, different consistency platforms must be identified and then, according to these platforms structure integrator needs to manage consistency daily. No consistency platform can be neglected because when it is virtual organization will have serious problems and the whole cooperation may just fail.

One of the regions of the world which is not explored well as for critical success factors of the organizations is Siberia region. This is part of Asia which becomes more and more popular nowadays for companies looking for their cooperation partners. In Siberia there are thousands of organizations having access to rare resources which may be used on a global scale (Chomiak-Orsa \& Flieger, 2012). This makes the region especially attractive for many organizations from Poland as well as from other parts of the world.

However, thinking about cooperation with Siberian organizations in terms of consistency concept requirements, there is a need to adjust 
to these organizations to be able to cooperate smoothly. One of the most important consistency platforms is corporate culture. In order to make cooperation mechanisms effective it is necessary to recognize corporate culture of Siberian organizations so that the strategies of cooperation may be developed. The main aim of the paper is to provide detailed description of corporate culture characteristics of Siberian organizations which may be the basic point for organizations from all over the world to adjust their cooperation mechanism in order to use Siberian CSFs effectively. It must be stated clearly that there is a huge gap in management knowledge as for corporate culture analysis of Siberian organizations. This way the main aim of this paper not only fills the knowledge gap but also has a very important application value - the research results presented in the paper may be very useful in decision making as for if to start the cooperation with Siberian organizations and if positive decision in made - how to adjust to their corporate culture to cooperate smoothly and sustain consistency in this area.

The support aim of the paper is to outline the directions in which Siberian organizations (workers) would like their corporate culture to be changed. These expectations have a crucial meaning for working out possible ways of cooperation in terms of corporate culture adjustments because managers of organizations wanting to explore Siberian CSFs have to develop cooperation mechanism according to what Siberian workers would like them to be (of course to the extend it is possible). Again, it needs to be stated clearly that there has not been knowledge about such expectations in management theory so far so there is a new set of information provided. Moreover, importance of the knowledge for practitioners needs to be stresses out as it will allow managers adjust to what is actually expected - the new knowledge shows cooperation strategies.

Such paper's aims have not only the importance because of filling the knowledge gap (theoretical contribution) and having application value (managerial contribution) but also may be a starting point for scholars to work on cooperation strategies in terms of corporate culture differences so that the consistency is sustained and CSFs of Siberian organizations are explored effectively and efficiently. 


\section{BACKGROUND}

Consistency concept is a new concept developed by the author of the paper and it will be introduced shortly later in the paper. Generally the basics of consistency in management literature can be traced back to K. Adamiecki who worked out harmony rule and work harmonization concept (Adamiecki, 1938). Harmonization in management may be also found in F. Taylor's works considering work effectiveness and Scientific Management issues (Taylor, 1919). Also H.L. Gantt who concentrated on work processes planning used harmonization issue as a base for his findings (Gantt, 1916). In the same management area should be placed time and motion study which was an example of work process management proposed by F.B. Gilbreth, L.E. Moller-Gilbreth (Gilbreth \& Gilbreth, 1919). Generally speaking, the early management scientists paved the way for consistency focusing on management harmonization as one of the main managerial aims in organizations.

Today's concept of harmonization has been developed by scholars who were pioneers in process orientation towards organization. They postulated the necessity to harmonize organization but not only from single work perspective (as classics did) but also from the perspective of organizational structure. According to F. Nordsieck the new way of organization structures should be based on processes and there is a need to harmonize organization from the two perspectives: static and dynamic (Nordsieck, 1997). F. Nordsieck formed a basis for process optimization as for process nests optimization (static) and as for mechanisms of their cooperation (dynamic). These perspectives gave a base for consistency concept in terms of cultural harmonization of virtual structures, which is the main perspective of this paper.

According to E. Kosiol the harmonization within organization needs to consider processes configuration within organization but also the work that takes place inside the processes (Kosiol, 1976). These two perspectives should be harmonized at the same time. Similar perspective was presented by M. Porter who stressed out that there needs to be harmonization between main and support processes in every organization (Porter, 1985). According to M. Porter only then will there be a coherent organizational structure allowing the company to operate smoothly towards clients' needs meeting. 
Very important background for the scientific base of this paper was brought by K. Perechuda who developed the idea of virtual structures and the use of CSFs for the sake of the client (Perechuda, 2000, p. 89). According to K. Perechuda virtual structures are one time ventures started by the company that is called integrator. The main role of the integrator is to find the idea of the product for the client, outline the process leading to the product, identifying CSFs needed to make each process operation best, inviting companies for cooperation, navigating the cooperation and finally selling the product. Here, the idea of using Siberian CSFs becomes valid.

The last author who formed the background for this paper was E. Schein who defined corporate culture as a set of consistent artefacts, norms and values and cultural traits (Schein, 2010). In this paper this definition became the base of the identification of the consistency platform (corporate culture) as well as the base for the research structure that was conducted by the author of this paper in Siberia.

\section{CONSISENCY CONCEPT AS THE BACKGROUND OF THE PAPER}

Consistency concept is a new idea in management theory which was developed by the author and introduced in 2016 (Flieger, 2016, pp. 21-31). The base of this concept was harmonization issue mentioned before as well as General Systems Theory introduced by L. Von Bertalanffy (Bertalanffy, 1968). According to the concept there are consistency platforms which need to be coordinated within each organization to form a consistent system. The identification of these platforms and description of the ways in which consistency should be achieved is the main interest of consistency concept.

Generally speaking, on strategic level of organization management, there are such consistency platforms as management concepts and management methods, organizational structures and management style and platforms mentioned above and human resource profile (Flieger, 2012, p. 88; Czerska \& Rutka, 1998, p. 172). All of these elements need to be matched together to form a consistent system. Moreover, there are other perspectives from which we may look at the organization in order to harmonize it in consistent system. For example, from corporate structure point of view, there is a need to harmonize 
strategic, tactic and operational levels of organization, which in process organizations may be a challenge. Main processes, support processes, nests' operations all need to be coordinated to achieve strategic goals of organization (Obłój, 1999, p. 120).

Another perspective of organizational consistency is connected with goals harmonization. In hybrid structures, where there is a traditional structure along with a process one, there is a need to build a consistent system of functional and process goals on all levels of the two structures (Chomiak-Orsa \& Flieger, 2011b, p. 64). This is often very difficult to achieve as the two structures focus usually on different perspectives and they set their goals using different optics. However, they need to be coordinated somehow to achieve company strategy.

One of the perspectives of consistency considers virtual structures. In such structures organizations from all over the world form one process structure and this fact makes it a big issue as for achieving consistency effect. As stated before, an integrator invites for cooperation organizations having CSFs and they cooperate in typical process relations: internal producers and internal clients. Thus, close cooperation and communication is necessary for the production to take place in an effective way (Pierścionek, 2003, p. 92). To build and sustain consistency here it is necessary to recognize corporate culture of the organizations with which we will cooperate. Such recognition will make it possible to decide if it is possible to cooperate in virtual structures in a given case and if yes, it will give crucial hints as for the directions in which cooperation mechanisms should be developed. This way consistency in this aspect will be achieved. As pointed out in the introduction section, the main aim of the paper considers characteristics of Siberian organizations corporate culture which will make it possible to use Siberian CSFs in an effective way.

\section{RESEARCH METHOD}

One of the main sections of this paper is presentation of research results considering corporate culture characteristics of Siberian organizations. The main research aims were:

1. Finding out main characteristics of corporate culture of Siberian organizations as for:

a. Language artefacts, behavior artefacts, material artefacts. 

b. Norms and values.
c. Culture traits.

2. Pointing out expected directions of change in areas $1 \mathrm{a}, 1 \mathrm{~b}$ and 1c which will be helpful to establish possible adjustments in cooperation mechanisms with Siberian organizations.

To achieve the above research aims the author conducted a research in 40 organizations from Siberia. The research was conducted in May 2018 in Irkuck and surrounding cities. The organizations which were chosen for the research came from different branches and were of different size, but all of them were business organizations. This way, after researching 40 different Siberian business organizations, the results may greatly reflect general picture of the researched topic. This way they may form universal knowledge which may be used by different organizations from all over the world wanting to cooperate with Siberian CSFs.

As for research methods three of them were used. First of the methods were anonymous questionnaires filled in by workers of different levels of the organizations. In total 156 questionnaires were collected during the research. Second method was personal interviews with managers and ordinary workers of some of the researched organizations which helped understand Siberian corporate culture problem better as well as helped define expected directions of corporate culture change more precisely. In total 30 interviews were conducted. The last method used was direct observation among workers during their working time, which was extremely useful and important to understand Siberian corporate culture more profoundly. In total 16 observations in 16 organizations were made. The results of the research were presented below.

\section{RESEARCH RESULTS}

\section{Corporate culture artefacts}

The first group of researched issues was cultural artefacts which may be divided into language, behavior and material artefacts. Language and behavior artefacts are especially important as they are quite easy to notice and it is relatively simple to make adjustments strategies as for these aspects. Moreover, language and behavior culture levels are very important for the effectiveness of cooperation as they directly 
influence communication process, which is crucial for effective cooperation especially in process structures. Effective communication between production nests is a necessary condition of cooperation - when there are communication problems probably virtual organization will fail. Thus, the results presented here are of the highest importance for any organization wanting to cooperate with Siberian partners.

As stated before, the research considered actual characteristics of corporate culture elements as well as expected directions of their change. The results considering language artefacts were grouped and synthetically presented in table 1 .

Table 1. Actual and expected language artefacts

\begin{tabular}{|c|c|}
\hline \multicolumn{2}{|c|}{ Language artefacts } \\
\hline Actual language artefacts & Expected language artefacts \\
\hline $\begin{array}{l}\text { Formal language, vague, general, orders style of } \\
\text { communication, lack of discussion/negotiation } \\
\text { with workers, aggressive way of communicating } \\
\text { between managers and workers and sometimes } \\
\text { between workers at the same level, official lan- } \\
\text { guage, unclear way of expressing thoughts, friendly } \\
\text { communications depending on informal relations, } \\
\text { often swearing, informal language in groups of } \\
\text { work friends, nice vocabulary of workers towards } \\
\text { managers (flattering), fear to communicate clearly } \\
\text { and openly in organization, sometimes rude lan- } \\
\text { guage toward clients, no open communication with } \\
\text { strangers and foreigners, rear foreign language } \\
\text { speaking abilities }\end{array}$ & $\begin{array}{l}\text { Open communication with } \\
\text { managers, nice vocabulary and } \\
\text { respect in communication process } \\
\text { especially between managers and } \\
\text { workers, low importance of infor- } \\
\text { mal relations influencing ways of } \\
\text { communication (equality in com- } \\
\text { munication process), possibility to } \\
\text { speak up freely, less swearing and } \\
\text { rude vocabulary, nicer language } \\
\text { while communicating with for- } \\
\text { eigners, English more widespread }\end{array}$ \\
\hline
\end{tabular}

Source: own research results.

As we may see in table 1 it is possible to give specific characteristics for language artefacts of Siberian organizations. The language there may be actually divided between formal, which is official, rather sharp, often rude, resembling orders giving (especially in a communication between managers and workers) and informal, which is usually in informal groups of friends and there the language is more friendly, open and discussion-like. What is characteristic is that in formal communication there is a tendency not to express real thoughts clearly and the language is often vague, listeners need to think hard about what actually the speaker thinks. This seems to be typical for all of Asian countries. 
Another very typical thing is the lack of open language and friendly conversations towards strangers and foreigners. In relations like these workers tend not to communicate, showing lack of trust and a kind of hostility. However, once you become friends with them, they change totally and treat you as the best friend in informal communication pattern. This shows another Asian characteristic - importance of personal relations and the way they change workers' attitude.

As for the way the workers would like the language artefacts to be changed, the research results show clearly that workers would like to be able to use straight language expressing their real feelings and they would like to see more openness in formal communication, with nicer vocabulary and respecting the listeners. They would also like to be able to speak foreign languages, although it is still a big problem for Siberian people in general.

Another aspect of artefacts considered typical behavior patterns of Siberian organizations as well as expected directions of change in this matter. The results are presented in table 2 .

Table 2. Actual end expected behavior artefacts of Siberian organizations

\begin{tabular}{|c|c|}
\hline \multicolumn{2}{|l|}{ Behaviour artefacts } \\
\hline Actual behaviour artefacts & $\begin{array}{c}\text { Expected behaviour } \\
\text { artefacts }\end{array}$ \\
\hline $\begin{array}{l}\text { Conservative, communicative, little-initiative, vague } \\
\text { (difficult to understand), nice and polite towards work } \\
\text { friends, active, optimistic, disciplined, hardworking, seri- } \\
\text { ous, kind, impulsive, highly regulated, responsible, a lot } \\
\text { of formal procedures, following rules, overtime work, lack } \\
\text { of creativity, lots of formalities, trust, punctual, sense of } \\
\text { duty, attentiveness, accuracy, training important, subor- } \\
\text { dinate, fallowing strictly procedure, enterprising, stress } \\
\text { resistant, lack of courage, plodding, reliable, non-conflict, } \\
\text { friendly, fast thinking, not too innovative, manifestation } \\
\text { of leadership and money }\end{array}$ & $\begin{array}{l}\text { More initiative and cre- } \\
\text { ativity, less strict rules } \\
\text { fallowing, less work load } \\
\text { resulting in tiredness, more } \\
\text { friendly relations, explicit } \\
\text { attitudes and roles }\end{array}$ \\
\hline
\end{tabular}

Source: own research results.

The results shown in table 2 show that behavior pattern in Siberian organizations corresponds closely with language artefacts described above. The behavior is rather formal, connected with discipline, fallowing rules, regulations and procedures. This is why there is rather no room for creative and innovative attitudes at work. However, workers are usually responsible, punctual and have sense of duty, so they obey all the rules and cope with stress and huge 
work load bravely. One thing that is quite visible is that there is also informal organization level where there are groups of friends who behave family-like at work. Such workers eat together, spend breaks together, bring food from home and share it with others, so there is a sense of community. It is a very typical characteristic that the author noticed many times in other parts of Russia as well. Again, it stresses the importance of informal and friendly relations for trust and generous treatment.

As for expected behavior pattern Siberian workers would like to have more room for creativity and innovativeness. As they usually work hard and spend at work long hours they would also appreciate better work coordination so that they do not need to work so long to do all they have to do. They also would like to see more friendly relations, especially with their managers.

Another cultural artefact which was researched was material artefacts. The results of the research are presented in table 3 .

Table 3. Actual and expected material artefacts in Siberian organizations

\begin{tabular}{|c|c|}
\hline \multicolumn{2}{|l|}{ Material artefacts } \\
\hline Actual material artefacts & $\begin{array}{c}\text { Expected material } \\
\text { artefacts }\end{array}$ \\
\hline $\begin{array}{l}\text { Problems with old machinery and equipment, not appro- } \\
\text { priate for new technology, more and more IT infrastructure } \\
\text { with internet use, security often neglected, sometimes ad- } \\
\text { vanced but mostly used up tools and infrastructure, slowly } \\
\text { improving, heritage of old system, official style of dressing, } \\
\text { mixture of casual and formal clothes, often no official dress } \\
\text { code, common ownership feeling towards equipment, often } \\
\text { lack of respect, nobody's property attitude, dirty, intensive } \\
\text { use of old fashioned infrastructure from soviet times }\end{array}$ & $\begin{array}{l}\text { Modern and safe, nice } \\
\text { to look at and be in } \\
\text { infrastructure, clean, no } \\
\text { official dress code but } \\
\text { neat casual style, more } \\
\text { responsibility and respect } \\
\text { when dealing with com- } \\
\text { pany infrastructure }\end{array}$ \\
\hline
\end{tabular}

Source: own research results.

The research results presented in table 3 reflect historic situation of the region in which the research took place. After many years of soviet domination material artefacts of Siberian organizations are characterized by old and worn machinery and tools, causing many daily problems and posing often numerous life hazards. Security is often neglected and the attitude to machinery and infrastructure is typical for communistic times, where infrastructure used to belong to the public. This fact made people not care and respect infrastructure and it can also be seen today. As for the dressing code Siberian workers 
dress rather neatly and formally, although in some organizations clothes were casual and old-fashioned. This is probably due to poor financial situation of many Siberian workers - they just cannot afford elegant and modern clothes.

Research results show clearly that workers would like to have more modern and more safe equipment in their organizations, although they seem to be used to the one they have and they usually do not complain. It is very typical characteristic of Siberian (and often generally Russian) people that they do not complain and accept reality as it is. This attitude can also be seen in the aspect of technical infrastructure. As for dressing style they prefer it to stay casual, but neat and clean.

\section{Corporate culture norms and values}

One of the most important area in which consistency is crucial but at the same time very difficult to achieve is the area of norms and values. Every organization has its own characteristic but the research results let give an outline of general norms and values which may be found in Siberian organizations. It was possible especially due to the big number of questionnaires and interviews made by the author. The results of actual and expected norms and values are presented in table 4 .

Table 4. Actual and expected norms and values in Siberian organizations

\begin{tabular}{|c|c|}
\hline \multicolumn{2}{|l|}{ Norms and values } \\
\hline Actual norms and values & $\begin{array}{l}\text { Expected norms } \\
\text { and values }\end{array}$ \\
\hline $\begin{array}{l}\text { Creative attitude towards difficulties encountered, } \\
\text { obeying rules, effective at work, morality and tradition } \\
\text { important, official attitudes to strangers, understanding, } \\
\text { no discrimination, workers' rights, responsibility for } \\
\text { duties, occasional violation of rules with no guilt feeling, } \\
\text { respect for others, strict regulations and no freedom of } \\
\text { actions taken for granted, detailed regulations, fairness, } \\
\text { bribery accepted and widespread, punctuality, care of } \\
\text { property, schedule important, peace and rest with fami- } \\
\text { lies and friends important, health care, honesty in friend } \\
\text { relations, trust, honor, tolerance, team work important, } \\
\text { sympathy, support, integrity important, obeying estab- } \\
\text { lished norms, kindness, respect, knowledge matters, } \\
\text { good relations with other workers important, fair, help- } \\
\text { ful with foreigners and strangers when introduced into } \\
\text { company, desire to win }\end{array}$ & $\begin{array}{l}\text { Less money making at all } \\
\text { costs, more trust towards } \\
\text { workers resulting in more } \\
\text { freedom of action, no bribery, } \\
\text { family and friends even more } \\
\text { important, work reorganiza- } \\
\text { tion for more free time and } \\
\text { less work load }\end{array}$ \\
\hline
\end{tabular}

Source: own research results. 
When we take a look at the results presented in table 4 it can be noticed that Siberian norms and values are characterized by hard work attitude, obeying rules and procedures, accepting lack of freedom of action, punctuality, support at work, respect, tolerance and lack of discrimination. Again, very important is friendship and trust, which seems to be crucial for good and close relations. Siberian workers are also very close with family, tradition and morality values and often create family-like atmosphere at work (but only when they are friends and know one another well). What seems to be widespread is bribery and unfortunately it is accepted in many cases. This information was given to the author in informal conversations.

As for expected changes in dominating norms and values researched workers often indicated less formal relations and more friendly atmosphere at work, trust and freedom which should be given from managers to workers and more free time value over money making aspect. Also bribery was condemned as it makes it difficult to do business based on rational decision making.

\section{Cultural traits}

Corporate culture elements presented above are deeply rooted in cultural traits which are crucial to understand organizations in a given country but at the same time are quite difficult to define. However, because the research was conducted in many organizations and among a big number of workers, using a few methods, the results reflect the main cultural traits of Siberian workers in terms of attitudes towards work and organization. It seems that these aspects are the most important for understanding consistency mechanisms needed in mutual cooperation. The results are presented in table 5 .

Research results presented in table 5 show that Siberian workers treat work and organization in the perspective of people they work with and relations they make. This seems to be the most important aspect of their attitude towards work and company. Thus, aspects of friendship, help, trust, interaction with others, effective communication, politeness, group working, assistance and new friends making is so important for Siberian workers. At the same time they accept the fact that they need to work in life, that good work is important and they are ready to work hard. Moreover, these workers are culturally 
prepared for fallowing rules, orders, procedures and regulations and family atmosphere seems to be a remedy to bear with those regulations and big work load resulting in long working hours.

Table 5. Actual and expected cultural traits in Siberian organizations

\begin{tabular}{|c|c|}
\hline \multicolumn{2}{|l|}{ Culture traits } \\
\hline $\begin{array}{l}\text { Actual culture attitudes towards work } \\
\text { and company }\end{array}$ & $\begin{array}{l}\text { Expected culture attitudes } \\
\text { towards work and company }\end{array}$ \\
\hline $\begin{array}{l}\text { Compulsory, importance for future life, difficult } \\
\text { and long, needs to be good for quality of life, useful, } \\
\text { making work friends important, communication and } \\
\text { belonging, history and tradition, honesty, responsi- } \\
\text { bility, discipline, tangible aspects matter, no racism, } \\
\text { strict rules making workers busy, time limits accept- } \\
\text { ed, team work, goals achieving atmosphere, fast work } \\
\text { and fast profits, strong partnership feeling, joy of } \\
\text { interaction, work for yourself and fast career making, } \\
\text { friends important, friendly cooperation, respect } \\
\text { for bosses, listening to orders, group important, } \\
\text { achieving common goals, proud to work for, hierarchy } \\
\text { important, work for own goals, privacy, politeness, } \\
\text { family-oriented, understand preferences and values } \\
\text { of others, interaction in teams and communication } \\
\text { matters, meeting new people, mutual assistance }\end{array}$ & $\begin{array}{l}\text { Eliminating ruthless career and } \\
\text { money making at all costs, long } \\
\text { time profits orientation, more } \\
\text { partnership between managers } \\
\text { and workers, less hierarchy } \\
\text { oriented, more trust for workers } \\
\text { resulting in more freedom and } \\
\text { creativity, belonging to orga- } \\
\text { nization feeling (responsibility } \\
\text { and feeling of ownership) }\end{array}$ \\
\hline
\end{tabular}

Source: own research results.

What Siberian workers do not like is fast profits orientation and money making at all costs. Such attitude, according to researched workers, should be eliminated and organizations should be more long-profits oriented, investing in people, trusting them and giving them more freedom. Siberian workers would like to be more independent and creative at work. This is probably so visible because of the generation change in Russia generally. Older generations, remembering old communistic system are ready to accept orders giving and sometimes rude treatment at work. However, young generations want to be treated with trust and respect and require more freedom of action using their qualities and knowledge (younger generation is usually better educated in Siberia than old one). More and more often workers want to feel that they are a part of organization and they want to identify with it. That is why working out consistency strategy for cooperation with Siberian partners it may be helpful to recognize the age of workers that are employed in organizations we will work with in virtual structures. 


\section{DISCUSSION}

The findings presented above have a critical value for organizations which are interested in inviting Siberian organizations to cooperate in joint projects. The knowledge gathered during the research is even more valuable when we take into consideration the fact that there has not been such a research so far.

Having a closer look at the findings previous researchers provided in their publications we will see that there have been some studies considering Russian corporate culture in general, especially in the context of transition from communistic to quasi-democratic economy (Fey \& Denison, 1998). In the studies authors mostly focus on the level to which Russian organizations are still communistic, or, another words, how much they have become similar in managements aspects to western organizations. Some authors compare corporate cultures of Russia and other countries and this way the main Russian characteristics are shown (Buck, 2003, pp. 299-313). There are also authors who try to understand Russian management culture through national culture and they try to answer the question how much of Russian cultural tradition can still be found in Russian organizations (Ralston, 1996).

Unfortunately, as stated above, no research has been dedicated to Siberian corporate culture so far. However, considering the fact that Siberia is a part of Asia, some knowledge about specific characteristics of Siberian corporate culture may be found in publications recognizing Asian corporate culture (Solfo, 2015). In such publications some typical traits of Asian corporate culture may be found but the authors mostly focus on countries like China, Japan and Korea so readers need to keep in mind that Siberia will have its own specific corporate culture.

In fact when we take into consideration the findings of research presented in this paper and compare it to the other authors' findings we can see that Siberian corporate culture is a mixture of European and Asian corporate culture characteristic. Moreover, the situation becomes even more complex when we consider communistic corporate culture on the one hand and new Russian aggressive capitalism on the other hand (Aller Petfood, 2016). All of these factors make Siberian corporate culture unique, which is a big challenge as for achieving consistency when cooperating with Siberian organizations. Moreover, it must be stated clearly that no other research before has focused 
on Siberian corporate culture from consistency standpoint. When we consider consistency we need to research corporate culture in a way that allows managers build consistency strategies, focusing on culture elements especially important for such strategies to be effective.

\section{CONCLUSIONS}

Consistency concept as the base of the studies presented in this paper stresses the necessity to focus on harmonization in different aspects of cooperation between organizations. When organizations want to cooperate using virtual structures they need to search for consistency platforms first and then try to work out cooperation strategies resulting in consistency within these platforms.

One of the most important aspects of consistency is corporate culture which usually differs between world regions and even between specific countries. Thus, recognition of corporate culture characteristics of the region we want to cooperate with is the first step towards consistency.

One of the regions which seems to be more and more interesting for international cooperation is Siberia, with its resources and geographical location. However, as literature research has shown, corporate culture of Siberian organizations has not been researched so far. This was one of the reasons why the research presented in this paper took place. The research results make a theoretical contribution to management knowledge and fill the gap present so far.

Moreover, consistency topic and the research results have managerial implications as well. First of all consistency concept draws managers' attention towards harmonization seen in a modern way. Second, the research provides managers with knowledge about actual corporate culture characteristics of Siberian organizations. Last, the research shows expectations of Siberian workers as for the directions they would like to see their corporate culture change. This way managers may try to adjust to these expectations when working out harmonization mechanisms according to consistency concept requirements.

Siberian corporate culture is very specific because there are many Asian influences as well as remnants of communistic system. Thus, it seems to be necessary to conduct deeper studies as for various aspects of Siberian organizations functioning to recognize them better. This 
knowledge will allow managers cooperate with Siberian partners more effectively.

Another research direction should consider working out consistency mechanisms taking into consideration Polish corporate culture characteristics and Siberian ones. This will have a considerate application value because managers could use this knowledge immediately when starting cooperation with Siberian organizations. Also authors from other countries may use the findings presented in this paper to compare their corporate culture with Siberian partners, show the main differences and work out harmonization mechanisms. This way critical success factors hidden in Siberian organizations could become more achievable for organizations from all over the world.

\section{REFERENCES}

Adamiecki, K. (1938). O istocie naukowej organizacji pracy. Zbiór prac z zakresu nauki i kierownictwa. Warszawa: BCPW.

Aller Petfood (2016). A new corporate culture in Russia. Innovation and People Magazine, www.globalpets.community/article/aller-petfood-russia (accessed: 9th April 2019).

Bertalanffy, L. (1968). General System Theory: Foundations, Development, Applications. New York: George Braziller Press.

Brol, R. (1997). Rola i zadania samorządu i administracji w realizacji strategii rozwoju turystyki. In: R. Brol (red.). Gospodarka lokalna w teorii i praktyce (pp. 35-55). Wrocław: Akademia Ekonomiczna we Wrocławiu.

Buck, T. (2003). Modern Russian corporate governance: Convergent forces or product of Russia's history? Journal of World Business, 38(4), 7-16

Chomiak-Orsa, I. \& Flieger, M. (2011a). Computeretizaton as the Improvement of Processes in Local Administration Offices. Wrocław: Uniwersytet Ekonomiczny we Wrocławiu.

Chomiak-Orsa, I. \& Flieger, M. (2011b). Zastosowanie technologii informatycznych w rozwoju społeczno-gospodarczym gmin. Wyniki badań. In: J. Korczak, H. Dudycz (red.). Informatyka ekonomiczna (pp. 55-67). Wrocław: Wyd. Uniwersytetu Ekonomicznego we Wrocławiu.

Chomiak-Orsa, I., Flieger, M. (2012). Stymulowanie lokalnego rozwoju gospodarczego. Próba oceny skuteczności działań pozabudżetowych gmin. Zeszyty Naukowe Wyższej Szkoty Oficerskiej Wojsk Ladowych im. gen. Tadeusza Kościuszki, 4(166), 177-185. 
Czerska, M. \& Rutka, R. (1998). Metody diagnozowania przedsiębiorstwa. Katowice: Wyd. Akademii Ekonomicznej w Katowicach.

Drucker, P.F. (1992). Innowacja i przedsiębiorczość. Warszawa: PWE.

Dziemianowicz, W. (1998). Rola władz samorządowych w stymulowaniu napływu bezpośrednich inwestycji zagranicznych. In: Z. Olesiński (red.). Bezpośrednie inwestycje zagraniczne (pp. 31-49). Warszawa: PWE.

Fey, C. \& Denison, D. (1998). Organizational Culture and Effectiveness: The Case of Foreign Firms in Russia. Stockholm: Institute of International Business.

Flieger, M. (2012). Zarzadzanie procesowe w urzędach gmin. Model adaptacji kryteriów dojrzałości procesowej. Poznań: WN UAM.

Flieger, M. (2016). Organizational consistency concept. Organizacja i Zarzadzanie, 2(34), 21-31.

Gantt, H.L. (1916). The Task and Bonus System. New York: Engineering Magazine. Gilbreth, F.B. \& Gilbreth, L.M. (1919). Applied Motion Study. London: Constable.

Kosiol, E. (1976). Organisation der Unternehmung, Bd. 2. Breslau: Auflage.

Kuciński, K. (2001). Przestrzenne powiązania firm. In: I. Fierla, K. Kuciński (red.). Lokalizacja przedsiębiorstw a konkurencyjność (pp. 89-101). Warszawa: SGH.

Nordsieck, F. (1997). Die Europäischen Meeresmuscheln (Bivalvia). Vom Eismeer bis Kapverden. Stuttgart: Verlag Eugen Ulmer.

Obłój, K. (1999). Strategia organizacji. Warszawa: PWE.

Perechuda, K. (2000). Zarzqdzanie przedsiębiorstwem przyszłości. Warszawa: Difin.

Pierścionek, Z. (2003). Strategie konkurencji i rozwoju przedsiębiorstwa. Warszawa: WN PWN.

Porter, M.E. (1985). Competitive Advantage. New York: Free Press.

Ralston, D. (1996). The Impact of National Culture and Economic Ideology on Managerial work Values. Hartford: University of Connecticut Press.

Schein, E. (2010). Organizational Culture and Leadership (4th ed.). Zurich: Ted Nellen Publishing.

Solfo, L. (2015). Asian Business Culture. Honkkong: The Asian Entrepreneur.

Taylor, F. (1919). The Principles of Scientific Management. New York: Harper and Brothers Publishers. 